\title{
PENGUMUMAN STOCK BUYBACK DAN REAKSI PASAR SAHAM (STUDI KASUS PERUSAHAAN DI BURSA EFEK INDONESIA)
}

\author{
Adhi Suwanto \\ E-mail: adhi.suwanto@yahoo.com \\ I Made Sudana \\ E-mail: imadesudana@yahoo.co.id \\ Program Magister Manajemen \\ Fakultas Ekonomi dan Bisnis Universitas Airlangga
}

\begin{abstract}
This study aims to examine the stock market reaction to the announcement of the stock buy back with two indicators of AAR and CAAR. The sample taken is a company that does the announcement of stock buy back in the period 2008 - 2013. Study also tested the market reaction between two groups of companies announcing stock buyback based on BAPEPAMLK regulations are used. The first group are companies conducting announcements of stock but back by BAPEPAM-LK regulations number XI.B.2 which is rules on stock buy back under normal conditions and the second group by BAPEPAM-LK regulation number XI.B.3 which is rules on stock buy back on market conditions potentially crisis. The results showed that there was a significant positive market reaction around the announcement of the stock buy back as indicated by the value of AAR and CAAR are significant. The results also showed that there were significant differences in market reaction between companies that stock buy back announcements reference to BAPEPAM -LK regulations number XI.B.2 with the companies referring to BAPEPAM -LK regulations number XI.B.3. Market reaction to the company that conducting stock buy back announcements with reference to the rules BAPEPAM-LK number XI.B.2 have been reacted all positively, whereas the company that refers to BAPEPAM -LK regulation number XI.B.3 there are some that have been reacted negatively.
\end{abstract}

Keywords : Buy back, Abnormal return, BAPEPAM-LK Regulation,. 


\section{PENDAHULUAN}

Ada dua cara bagi perusahaan dalam memperlakukan keuntungan bersih yang didapat perusahan, yaitu menhanan di perusahaan dalam bentuk laba ditahan (retained earning) dan dibagikan kepada pemegang saham (payout policy). Payout policy ini bisa dilakukan dengan dua cara juga yaitu dibagikan dalam bentuk deviden (cash devidend), dan melakukan pembelian kembali saham yang beredar (stock buyback). Sebagai salah satu alternatif pendistribusian dana kas kepada pemegang saham, pembelian kembali saham semakin banyak dilakukan oleh perusahaan sebagai alternatif pengganti pembayaran deviden. Perusahaan akan melakukan pembelian saham kembali apabila memiliki dana lebih (excessive cash) yang diperoleh dari keuntungan perusahaan dan peluang investasi kedepan yang relatif kurang menjanjikan. Hasil pembelian saham kembali oleh perusahaan dapat disimpan sebagai treasury stock dengan tujuan untuk dijual kembali apabila harga saham perusahaan sudah sesuai dengan nilai seharusnya.

Pada tahun 2008, saat krisis ekonomi di Amerika Serikat membawa dampak ke hampir semua negara-negara di dunia termasuk di Indonesia. Di Indonesia, dampak dari krisis tersebut adalah terjadi penurunan yang signifikan indeks harga saham gabungan di Bursa Efek Indonesia. Hampir semua harga saham perusahaan-perusahaan yang tercatat di BEI mengalami koreksi yang cukup tajam terutama saham-saham papan atas (blue chips), sehingga mengakibatkan IHSG turun hingga $51.17 \%$ dari 2.830 menjadi 1.340 .

BAPEPAM-LK sebagai otoritas bursa waktu itu merespon dengan mengeluarkan peraturan No. XI.B.3 pada tanggal 10 Oktober 2008 tentang pembelian kembali saham oleh emiten atau perusahaan publik dalam kondisi pasar yang berpotensi krisis sebagai pengganti peraturan tentang pembelian kembali saham No. XI.B.2. Dengan dikeluarkannya peraturan baru tentang stock buy back tersebut diharapkan dapat mengurangi penurunan indeks harga saham gabungan di bursa sebagai dampak dari krisis keuangan global yang melanda pasar modal di seluruh dunia. Dalam peraturan No. XI.B.3 tersebut BAPEPAM-LK memperlonggar aturan dalam pembelian saham kembali, seperti tidak wajib mendapat persetujuan rapat umum pemegang saham, batas maksimal pembelian saham menjadi $20 \%$ dari modal disetor, serta tidak adanya pembatasan besarnya volume pembelian kembali saham dalam satu hari. Peraturan baru yang mempermudah tata cara pembelian kembali saham tersebut direspon dengan baik oleh beberapa perusahaan yang ditandai dengan melonjaknya jumlah perusahaan yang melakukan pengumuman pembelian saham kembali pada periode tahun 2008 sampai tahun 2009. Setelah kondisi harga saham membaik, maka peraturan No. XI.B.3 ini kembali dicabut oleh BAPEPAM-LK pada tanggal 10 April 2010 dan memberlakukan kembali peraturan No. XI.B.2. Selama periode tahun 2008 - tahun 2013 terdapat 90 perusahaan yang melakukan pengumuman pembelian kembali saham, terdiri atas 49 perusahaan mengacu pada peraturan No. XI.B.3 dan 41 perusahaan mengacu pada peraturan No. XI.B.2 Dampak dari pengumuman pembelian kembali saham tampak pada reaksi pasar yang salah satunya diukur dengan abnormal return saham pada hari-hari selama pengamatan (Ariyanto dan Rinaningtias, 2009).

Menurut penelitian sebelumnya pengumuman pembelian kembali saham memberikan sinyal positif bagi investor, sehingga meningkatkan minat investor terhadap saham perusahaan yang melakukan buy back. (Stephens \& Maxwell, 2003; Rahma, 2009; Nishikawa et al, 2011; Rasbrant, 2011; Junizar, 2013). 
Pada penelitian ini di samping menguji reaksi pasar terhadap pengumuman pembelian kembali saham pada semua perusahaan yang termasuk dalam sampel penelitian, juga akan membandingkan perbedaan reaksi pasar pada perusahaan yang dalam pembelian kembali sahamnya mengacu pada peraturan BAPEPAM-LK No. XI.B.2 dengan perusahaan yang mengacu pada peraturan BAPEPAM-LK No. XI.B.3 pada periode tahun 2008 - tahun 2013.

\section{TINJAUAN PUSTAKA}

\section{Penelitian sebelumnya}

Maxwell dan Stephens (2003) meneliti dampak pengumuman buy back terhadap pasar saham dan pasar obligasi. Pada penelitian tersebut dilakukan pengamatan terhadap perubahan peringkat obligasi di sekitar tanggal pengumuman untuk melihat apakah terjadi wealth transfer dari pemegang obigasi ke pemegang saham. Dari hasil penelitian didapatkan bahwa abnormal return saham bernilai positif, sedangkan untuk return obligasi bernilai negatif walaupun tidak signifikan.

Lestari (2008) meneliti dampak pengumuman pembelian kembali saham terhadap return saham berdasarkan alasan perusahaan melakukan pembelian kembali saham. Perusahaan dikelompokkan menjadi dua kelompok berdasarkan alasan melakukan buy back, yaitu meningkatkan harga saham melalui peningkatan laba bersih perlembar saham dan meningkatkan harga saham melalui peningkatan dividen perlembar saham. Dalam penelitian tersebut perusahaan yang melakukan pembelian kembali saham juga diuji berdasarkan tingkat pertumbuhannya dengan menggunakan Tobin $\mathrm{Q}$, dimana perusahaan juga dibagi menjadi dua kelompok perusahaan berdasarkan nilai Tobin $Q$ yaitu kelompok perusahaan dengan pertumbuhan tinggi dan kelompok perusahaan dengan pertumbuhan rendah. Hasil penelitian yang didapat adalah bahwa tidak terjadi perbedaan yang signifikan pada pengelompokan perusahaan berdasarkan alasan melakukan pembelian kembali saham. Pada pengelompokan perusahaan yang melakukan pembelian kembali saham berdasarkan tingkat nilai Tobin $Q$ terjadi perbedaan yang signifikan antara perusahaan dengan tingkat pertumbuhan tinggi dengan perusahaan dengan tingkat pertumbuhan rendah.

Penelitian tentang buy back juga dilakukan oleh Mulia (2009), yang menguji pengaruh pengumuman pembelian kembali saham terhadap bondholder, stockholder dan value perusahaan. Data yang digunakan adalah 30 pengumuman pembelian kembali saham pada periode 2001-2007. Dari hasil penelitian ditemukan, bahwa nilai average abnormal return dan cummulative abnormal return yang secara signifikan bernilai positif disekitar tanggal pengumuman, yang mengindikasikan terjadinya wealth effect kepada pemegang saham. Di samping itu ditemukan bahwa cashflow dan undervaluation berpengaruh signifikan terhadap besar CAR. Dari sisi peringkat obligasi baik prediksi maupun aktual, sebagian besar tidak menunjukkan adanya penurunan peringkat setelah pengumuman buy back. Begitu juga dengan value perusahaan mengalami peningkatan, sehingga menguntungkan pemegang saham.

Nishikawa et al (2011) melakukan penelitian untuk menguji dampak wealth transfer dari pemegang obligasi ke pemegang saham dengan adanya program pembelian kembali saham dengan cara pembelian melalui pasar terbuka (open market). Dampak pembelian kembali tersebut dilihat melalui reaksi pasar saham dan obligasi, serta memeriksa wealth effect 
transfer dengan mengklasifikasikan subsampel berdasarkan atribut sensitif terhadap dampak transfer kekayaan, termasuk peringkat obligasi, ukuran pembelian kembali, keberadaan perjanjian dividen, dan pendapatan saham. Hasilnya adalah terjadi perubahan abnormal return saham positif secara signifikan, sedangkan untuk instrumen obligasi menunjukkan penurunan harga negatif secara signifikan.

Rasbrant (2011) melakukan penelitian untuk melihat pengaruh dari pengumuman transaksi buy back dengan metode open market repurchase terhadap reaksi pasar bursa di Swedia dengan data yang diperoleh dari NASDAQ OMX Stockholm. Reaksi pasar diproksikan dengan abnormal return dan uji melalui metode event study. Hasil penelitian mendokumentasikan bahwa pengumuman informasi buy back berpengaruh signifikan menaikkan abnormal return perusahaan-perusahaan Swedia yang melakukan buy back sebesar $1,94 \%$, adapun return perusahaan juga mengalami kenaikan positif.

Penelitian tentang buy back selanjutnya dilakukan oleh Nittayagasetwat et al (2013) dengan mengambil sampel 78 pengumuman di stock exchange of Thailand (SET). Metode penelitian untuk mengamati reaksi pasar yang digunakan adalah dengan event study. Penelitian tersebut ditujukan untuk mengetahui efek pengumuman pembelian kembali saham terhadap abnormal return perusahaan disekitar tanggal pengumuman. Hasil penelitian yang didapat adalah terdapat abnormal return positif sebesar rata-rata $2.23 \%$, dengan level of significance $1 \%$.

Penelitian mengenai pengaruh suatu event atau kejadian terhadap reaksi pasar antara lain juga dilakukan oleh Junizar (2013). Dalam penelitian tersebut data yang digunakan sebagai sampel akhir adalah 20 pengumuman pembelian kembali saham. Sebagaimana penelitian yang lain metode penelitian yang digunakan untuk mengetahui reaksi pasar di sekitar pengumuman adalah event study. Hasil penelitian tersebut menemukan adanya peningkatan positif signifikan terhadap variabel abnormal return dan trading volume activity di sekitar pengumuman. Pada penelitian tersebut juga ditemukan bahwa terjadi perbedaan average abnormal return (AAR) dan average trading volume activity (ATVA) yang signifikan pada 5 hari sebelum dengan 5 hari setelah pengumuman buy back dilakukan.

\section{Tinjauan Teoritis}

\section{Pendapatan Saham}

Pendapatan merupakan hasil yang diperoleh dari sebuah investasi saham yang berupa pendapatan aktual (actual return) atau pendapatan ekpektasi (expected return). Pendapatan aktual merupakan pendapatan yang sudah terjadi maka perhitungannya didasarkan pada data historis harga saham. Pendapatan aktual merupakan salah satu pengukur kinerja perusahaan dan data historis dari pendapatan aktual dapat dipergunakan sebagai dasar dalam penentuan pendapatan ekspektasi. Pendapatan aktual merupakan pendapatan keseluruhan dari suatu investasi dalam suatu periode tertentu. Pendapatan aktual terdiri dari keuntungan modal (capital gain) atau kerugian modal (capital loss) dan yield. Pendapatan aktual biasa disebut juga dengan return saja dan dinyatakan dalam rumusan :

Return $=$ Capital Gain $($ Loss $)+$ Yield $\ldots \ldots \ldots \ldots \ldots 1)$ 
Capital gain (loss) merupakan selisih dari harga investasi sekarang relatif dengan harga periode lalu. Jika harga investasi sekarang $\left(\mathrm{P}_{\mathrm{t}}\right)$ lebih tinggi dari harga investasi periode lalu $\left(\mathrm{P}_{\mathrm{t}-1}\right)$ berarti terjadi keuntungan modal, jika sebaliknya maka terjadi kerugian modal. Yield merupakan persentase penerimaan kas periodik terhadap harga investasi periode tertentu. Untuk saham, yield adalah persentase deviden terhadap harga saham periode sebelumnya. Pada penelitian ini pendapatan saham hanya memperhitungkan capiatal gain saja, yang dihitung berdasarkan harga penutupan harian. Pendapatan aktual dapat diformulasikan sebagai berikut :

$$
R_{i t}=\frac{P_{t}-P_{t-1}}{P_{t}}
$$

Keterangan :

$\mathrm{R}_{\mathrm{it}}=$ Pendapatan saham i pada hari $\mathrm{t}$

$\mathrm{P}_{\mathrm{t}}=$ harga sekuritas pada periode $\mathrm{t}$

$\mathrm{P}_{\mathrm{t}-1}=$ harga sekuritas pada periode $\mathrm{t}-1$

Penelitian yang dilakukan Brown dan Warner (dalam Bahrum, 2009) menyatakan bahwa pendapatan ekspektasi merupakan return yang harus diestimasi. Mengestimasi pendapatan ekspektasi dapat menggunakan 3 model yaitu mean-adjusted model, market model, dan market adjusted model. Pada penelitian ini pendapatan yang diharapkan $E(R)_{i t}$ diukur dengan market adjusted model sebagai berikut:

$$
\left.E\left(R_{i t}\right)=R M_{t} \ldots \ldots \ldots \ldots \ldots . \ldots . \ldots\right)
$$

Pendapatan pasar $\left(\mathrm{RM}_{\mathrm{t}}\right)$ diukur dengan rumus:

$$
R M_{t}=\frac{I H S G_{t}-I H S G_{t-1}}{I H S G_{t-1}}
$$

Keterangan:

$\mathrm{IHSG}_{\mathrm{t}}=$ Indeks hagra saham gabunga pada hari $\mathrm{t}$

$\mathrm{IHSG}_{\mathrm{t}-1}=$ Indeks harga saham gabungan hari $\mathrm{t}-1$

Pendapatan abnormal atau abnormal return merupakan selisih antara pendapatan yang sesungguhnya terjadi (actual return) dengan pendapatan ekspektasi (expected return) (Jogianto, 2001). Menurut Jogiyanto (2005), studi peristiwa menganalisis abnormal return 
dari sekuritas yang mungkin terjadi disekitar pengumuman dari suatu peristiwa. Abnormal return atau excess return merupakan kelebihan dari return yang sesungguhnya terjadi terhadap return normal. Abnormal return dapat dihitung dengan rumus:

$$
\left.\mathrm{AR}_{\mathrm{it}}=\mathrm{R}_{\mathrm{it}}-\mathrm{E}\left(\mathrm{R}_{\mathrm{it}}\right) \ldots \ldots \ldots \ldots \ldots \ldots \ldots\right)
$$

Keterangan :

$$
\begin{array}{ll}
\mathrm{AR}_{\mathrm{it}} \quad \text { : Abnormal return saham i pada hari } \mathrm{t} \\
\mathrm{R}_{\mathrm{it}} \quad \text { : Tingkat pengembalian i aktual saham i pada hari } \mathrm{t} \\
\mathrm{E}\left(\mathrm{R}_{\mathrm{it}}\right) \text { : Tingkat pengembalian yang diharapkan saham i pada hari } \mathrm{t}
\end{array}
$$

Pengujian adanya abnormal return tidak dilakukan untuk masing-masing sekuritas, tetapi dilakukan secara agregat dengan menguji rata-rata abnormal return seluruh sekuritas secara cross section untuk tiap-tiap hari di periode peristiwa (event periode).

$$
A A R_{t}=\frac{\sum A R_{i t}}{N}
$$

Keterangan :

AAR,t : Average abnormal return pada hari ke-t

ARi,t : Abnormal return untuk saham i pada hari ke-t

$\mathrm{N} \quad$ : Jumlah sekuritas

Akumulasi rata-rata pendapatan tidak normal atau cummulative average abnormal return merupakan penjumlahan rata-rata pendapatan tidak normal (average abnormal return) untuk hari sebelumnya. Cummulative average abnormal return dirumuskan sebagai berikut :

$$
C A A R=\sum A A R, t \ldots \ldots \ldots \ldots \ldots+\cdots,
$$

Keterangan :

CAAR : akumulasi rata-rata pendapatan tidak normal (average abnormal return) pada hari ke-t 


\section{Efisiensi Pasar Modal}

Fama (1970) mengklasifikasikan bentuk pasar yang efisien ke dalam tiga efficient market hypothesis (EMH), yaitu:

\section{Efisiensi Pasar Bentuk Lemah (weak form)}

Pasar dikatakan efisien dalam bentuk lemah jika harga surat berharga saat ini betul-betul menggambarkan seluruh informasi yang terkandung dalam harga-harga surat berharga di masa-masa lalu. Informasi masa lalu merupakan informasi yang sudah terjadi. Jika pasar efisien dalam bentuk lemah, maka nilai-nilai masa lalu tidak dapat dipergunakan untuk memprediksi harga sekarang. Ini berarti bahwa untuk pasar yang efisien dalam bentuk lemah investor tidak dapat menggunakan informasi masa lalu untuk mendapatkan abnormal return.

2. Efisiensi Pasar Bentuk Setengah Kuat (semi strong form)

Pasar dikatakan efisien dalam bentuk setengah kuat jika harga-harga surat berharga betulbetul menggambarkan seluruh informasi yang dipublikasikan.

Jadi tak seorang pun investor yang mampu memperoleh tingkat pengembalian yang berlebihan dengan hanya menggunakan sumber-sumber informasi yang dipublikasikan. Termasuk jenis informasi ini adalah laporan tahunan perusahaan atau informasi yang disajikan dalam prospektus, informasi mengenai posisi perusahaan pesaing, maupun harga saham historis.

3. Efisiensi Pasar Bentuk Kuat (strong form)

Pasar dikatakan efisien dalam bentuk kuat jika harga sekuritas secara penuh mencerminkan semua informasi yang tersedia, termasuk informasi yang privat. Jika pasar modal efisien dalam bentuk ini maka tidak ada individual atau grup dari investor yang dapat memperoleh abnornal return.

\section{MODEL ANALISIS}

Untuk mengukur reaksi pasar terhadap suatu peristiwa yang terjadi pada perusahaan salah satu metode yang digunakan adalah event study. Event window ditentukan selama 7 (tujuh) dari sebelum event date (H-7) sampai dengan 7 (tujuh) hari setelah event date $(\mathrm{H}+7)$. 


\section{Kerangka pemikiran}

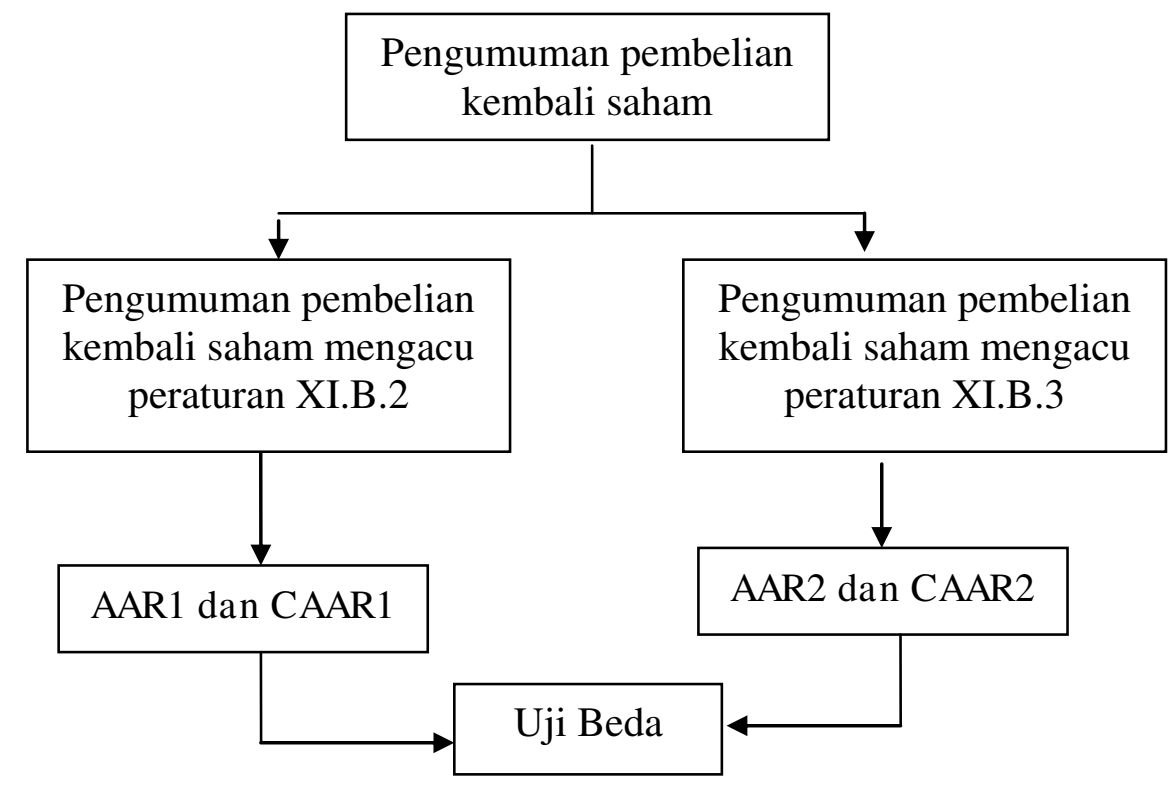

\section{PERUMUSAN HIPOTESIS}

Pengumuman program pembelian saham kembali adalah sinyal yang berharga ke pasar. Jika pasar modal adalah semi-efisien, harga ekuilibrium baru harus segera sepenuhnya mencerminkan nilai yang "benar" dari informasi baru (Rasbrant, 2011). Transaksi buy back sebagai suatu event yang dianggap memiliki pengaruh penting ini diharapkan akan memberikan suatu dampak atau reaksi kepada return saham. Penelitian yang dilakukan Maxwell dan Stephens (2003) dan Nishikawa et al., (2011) menyimpulkan bahwa buy back memiliki kandungan informasi yang menguntungkan (good news) bagi pemegang saham, sehingga abnormal return saham akan cenderung bergerak ke arah positif, sejalan dengan signaling theory yang menyatakan bahwa informasi yang dianggap menguntungkan akan memberikan reaksi pasar yang positif Junizar (2013).

$\mathrm{H}_{1}$ : Terdapat reaksi pasar yang positif atas pengumuman stock buy back di sekitar tanggal pengumuman pembelian kembali saham yang ditunjukkan oleh abnormal return yang siginifikan.

Dengan dikeluarkannya peraturan baru tentang pembelian kembali saham dalam kondisi pasar berpotensi krisis yaitu peraturan BAPEPAM-LK No. XI.B.3 yaitu diharapkan dapat membawa dampak pengurangan penurunan indeks harga saham gabungan (IHSG). Sesuai dengan hipotesis sinyal informasi bahwa perusahaan yang melakukan pembelian saham kembali bertujuan untuk memberikan informasi atau sinyal positif kepada para pemegang saham mengenai kondisi perusahaan. Akan tetapi ketika kondisi suatu negara menghadapi ancaman krisis keuangan, maka tingkat kepercayaan investor terhadap faktor fundamental 
ekonomi secara keseluruhan akan lebih berpengaruh daripada sinyal informasi yang dikeluarkan oleh perusahaan dalam bentuk pengumuman pembelian kembali saham.

$\mathrm{H}_{2}$ : Terdapat perbedaan rata-rata abnormal return yang signifikan antara pengumuman stock buyback perusahaan yang mengacu pada peraturan BAPEPAM-LK No. XI.B.2 dengan pengumuman stock buyback perusahaan yang mengacu pada peraturan BAPEPAM-LK No. XI.B.3.

\section{METODE PENELITIAN}

\section{Definisi Operasional Variabel}

Abnormal return (AR), yaitu selisih antara pendapatan actual dengan pendapatan yang diharapkan dan diukur dengan rumus no. 5)

Untuk menguji rekasi pasar atas pengumuman pembelian kembali saham setiap hari selama periode uji digunakan average abnormal return (AAR) yang diukur dengan rumus 6) dan cummulative average abnormal return (CAAR) yang diukur dengan rumus 7 )

\section{Prosedur Penentuan Sampel}

Dalam penelitian ini digunakan metode purposive sampling. Data yang digunakan diseleksi berdasarkan kriteria-kriteria, yaitu :

1. Data penelitian yang digunakan adalah data-data dari perusahaan yang tercatat pada Bursa Efek Indonesia pada periode tahun 2008 - tahun 2013 yang melakukan buy back.

2. Event date dibedakan menjadi dua, yaitu :

a. Perusahaan yang melakukan pengumuman pembelian kembali saham dengan mengacu pada peraturan BAPEPAM-LK No. XI.B.2 adalah tanggal persetujuan dari rapat umum pemegang saham luar biasa atas rencana perusahaan untuk melakukan stock buy back.

b. Perusahaan yang melakukan pengumuman pembelian kembali saham dengan mengacu pada peraturan BAPEPAM-LK No. XI.B.3 adalah tanggal pengumuman rencana pembelian kembali saham kepada PT. Bursa Efek Indonesia.

3. Saham perusahaan yang diteliti diperdagangkan secara aktif selama periode penelitian.

4. Perusahaan yang diteliti tidak melakukan aksi korporasi lain selain buy back saham seperti pembagian deviden, stock split, stock reverse, dan lain-lain pada periode pengamatan. 


\section{GAMBARAN UMUM OBYEK PENELITIAN}

\section{Pengelompokan Perusahaan yang Melakukan Pembelian Saham Berdasarkan Peraturan BAPEPAM-LK yang Digunakan}

Perusahaan yang melakukan pembelian kembali saham yang mengacu pada peraturan BAPEPAM-LK No. XI.B.2 dikelompokkan dalam kelompok 1 dan perusahaan yang melakukan pengumuman pembelian kembali saham dengan mengacu pada peraturan BAPEPAM-LK No. XI.B.3 dikelompokkan dalam kelompok 2.

Tabel 1. Pengelompokkan Perusahaan yang Melakukan Pengumuman Pembelian

Kembali Saham Berdasarkan Peraturan BAPEPAM-LK yang Digunakan.

\begin{tabular}{|c|c|c|c|c|c|}
\hline No. & $\begin{array}{c}\text { Kode } \\
\text { Emiten }\end{array}$ & $\begin{array}{c}\text { Tanggal } \\
\text { Pengumuman }\end{array}$ & No. & $\begin{array}{c}\text { Kode } \\
\text { Emiten }\end{array}$ & $\begin{array}{c}\text { Tanggal } \\
\text { Pengumuman }\end{array}$ \\
\hline \multicolumn{3}{|c|}{$\underset{1}{\text { KELOMPOK }}$} & \multicolumn{3}{|c|}{$\begin{array}{l}\text { KELOMPOK } \\
2\end{array}$} \\
\hline 1 & PNLF & 28 Juni 2008 & 1 & TLKM & 12 Okt 2008 \\
\hline 2 & PNIN & 28 Juni 2008 & 2 & BUMI & 13 Nop 2008 \\
\hline 3 & PNIN & 18 Sept 2013 & 3 & SCMA & 13 Okt 2008 \\
\hline 4 & TLKM & 20 Juni 2008 & 4 & SGRO & $11 \mathrm{Okt} 2008$ \\
\hline 5 & TLKM & 25 Mei 2011 & 5 & LSIP & 12 Okt 2008 \\
\hline 6 & MEDC & 17 Aprl 2008 & 6 & WIKA & 11 Okt 2008 \\
\hline 7 & BUMI & 12 Juni 2008 & 7 & ELSA & 17 Des 2008 \\
\hline 8 & BUMI & 23 Agst 2011 & 8 & SMGR & 12 Okt 2008 \\
\hline 9 & TBLA & 30 April 2008 & 9 & ANTM & 12 Okt 2008 \\
\hline 10 & LSIP & 23 April 2013 & 10 & JSMR & 12 Okt 2008 \\
\hline 11 & LPKR & 15 Nop 2011 & 11 & ADHI & 12 Okt 2008 \\
\hline 12 & LPKR & 13 Jan 2012 & 12 & PGAS & 22 Des 2008 \\
\hline 13 & AKPI & 1 Juli 2011 & 13 & APOL & 12 Okt 2008 \\
\hline 14 & KPIG & 26 Jan 2011 & 14 & BUDI & 16 Okt 2008 \\
\hline 15 & KPIG & 23 Pebr 2012 & 15 & TINS & 12 Okt 2008 \\
\hline
\end{tabular}




\begin{tabular}{|c|c|c|c|c|c|}
\hline 16 & CTRP & 9 Mei 2011 & 16 & BTEL & 15 Okt 2008 \\
\hline 17 & CTRP & 10 Juni 2012 & 17 & ELTY & 14 Okt 2008 \\
\hline 18 & PTBA & 3 Juli 2012 & 18 & ACES & 20 Okt 2008 \\
\hline 19 & SIMP & 23 April 2013 & 19 & JTPE & 27 Okt 2008 \\
\hline 20 & WINS & 21 Mei 2013 & 20 & JPRT & 15 Okt 2008 \\
\hline 21 & BMTR & 29 Agst 2013 & 21 & MICE & 15 Okt 2008 \\
\hline 22 & BCAP & 29 Agst 2013 & 22 & BLTA & 12 Okt 2008 \\
\hline 23 & BHIT & 29 Agst 2013 & 23 & MNCN & 17 Okt 2008 \\
\hline 24 & PNBN & 3 Sept 2013 & 24 & PKPK & 15 Okt 2008 \\
\hline 25 & CMNP & 5 Sept 2013 & 25 & INDF & 1 Des2008 \\
\hline 26 & RBMS & 10 Sept 2013 & 26 & AKPI & 19 Peb 2010 \\
\hline 27 & SSIA & 11 Sept 2013 & 27 & CPIN & 19 Okt 2010 \\
\hline 28 & MSKY & 13 Sept 2013 & & & \\
\hline 29 & SMBR & 16 Sept 2013 & & & \\
\hline 30 & DILD & 17 Sept 2013 & & & \\
\hline 31 & MLIA & 22 Okt 2013 & & & \\
\hline 32 & ECII & 27 Nop 2013 & & & \\
\hline 33 & BBRM & 16 Des 2013 & & & \\
\hline
\end{tabular}

Sumber: www.idx.com diolah

\section{Diskripsi hasil penelitian}

Diskripsi pendapatan aktual saham perusahaan berdasarkan pengelompokan penggunaan peraturan BAPEPAM-LK dalam pembelian kembali saham, hasilnya dipaparkan pada Tabel 2 . 


\section{Tabel 2: Pendapatan Aktual Saham Perusahaan Yang Melakukan Buy Back Saham}

Berdasarkan Pengelompokan Penggunaan Peraturan BAPEPAM-LK

\begin{tabular}{|c|c|c|c|c|c|c|}
\hline \multirow{2}{*}{ Hari } & \multicolumn{3}{|c|}{ Kelompok 1 } & \multicolumn{3}{c|}{ Kelompok 2 } \\
\cline { 2 - 7 } Ke- & Min & Max & Mean & Min & Max & Mean \\
\hline H-7 & -0.1000 & 0.0684 & -0.0094 & -0.1304 & 0.0526 & -0.0195 \\
H-6 & -0.0435 & 0.1157 & 0.0141 & -0.1200 & 0.0548 & -0.0210 \\
H-5 & -0.1857 & 0.0595 & -0.0076 & -0.0721 & 0.1234 & 0.0006 \\
H-4 & -0.1316 & 0.1111 & 0.0045 & -0.2816 & 0.0200 & -0.0842 \\
H-3 & -0.0235 & 0.2121 & 0.0170 & -0.2030 & 0.0430 & -0.0621 \\
H-2 & -0.1622 & 0.0821 & -0.0102 & -0.0994 & 0.1000 & 0.0069 \\
H-1 & -0.0656 & 0.1143 & 0.0128 & -0.0966 & 0.0130 & -0.0200 \\
H0 & -0.0735 & 0.0621 & 0.0012 & -0.1724 & 0.0705 & -0.0288 \\
H+1 & -0.0409 & 0.2261 & 0.0351 & -0.1000 & 0.0973 & 0.0065 \\
H+2 & -0.0194 & 0.1348 & 0.0128 & -0.0973 & 0.0999 & 0.0401 \\
H+3 & -0.0563 & 0.1571 & 0.0049 & -0.1000 & 0.0994 & 0.0060 \\
H+4 & -0.0448 & 0.0313 & -0.0012 & -0.1765 & 0.0870 & -0.0300 \\
H+5 & -0.0272 & 0.3600 & 0.0154 & -0.1838 & 0.0884 & -0.0429 \\
H+6 & -0.0435 & 0.0391 & -0.0075 & -0.1875 & 0.0252 & -0.0422 \\
H+7 & -1.0000 & 0.0476 & -0.0449 & -0.0956 & 0.1449 & -0.0056 \\
\hline
\end{tabular}

Sumber: Data diolah

Pada kelompok 1, actual return tertinggi ditemukan pada $\mathrm{H}+5$ dengan nilai 0.3600 dan actual return terendah ditemukan pada $\mathrm{H}-7$ dengan nilai -1.000 . Untuk average actual return tertinggi ditemukan pada $\mathrm{H}+1$ dengan nilai 0.0643 dan average actual return terendah ditemukan pada $\mathrm{H}+7$ dengan nilai -0.0001 . Pada kelompok 2, actual return tertinggi ditemukan pada $\mathrm{H}+7$ dengan nilai 0.1449 dan actual return terendah ditemukan pada $\mathrm{H}-4$ dengan nilai -0.2816 . Untuk average actual return tertinggi ditemukan pada $\mathrm{H}+2$ dengan nilai 0.0401 dan average actual return terendah ditemukan pada H-3 dengan nilai -0.0621 . 


\section{ANALISIS DAN PEMBAHASAN}

Reaksi pasar terhadap pengumuman pembelian kembali saham diukur dengan melakukan pengujian abnormal return selama periode uji (event windows). Abnormal return ini diukur dengan menggunakan indikator AAR dan CAAR. Untuk mengetahui apakah ada perbedaan reaksi pasar yang signifikan antara pengumuman pembelian kembali saham perusahaan yang mengacu pada peraturan BAPEPAM-LK No. XI.B.2 dengan yang mengacu pada peraturan BAPEPAM-LK No. XI.B.3, maka dilakukan pengelompokan sampel berdasarkan dua jenis perusahaan yang melakukan pengumuman pembelian saham kembali. Kemudian dengan menggunakan indikator AAR dan CAAR masing-masing kelompok tersebut dilakukan uji $\mathrm{t}$ dua sampel dua arah dengan $(\alpha)=5 \%$.

\section{Reaksi Pasar Terhadap Pengumuman Pembelian Kembali Saham}

Hasil analisis dan pengujian hipotesis reaksi pasar terhadap pengumuman pembelian kembali saham untuk keseluruhan sampel dipaparkan pada Tabel 3.

Tabel 3: Average Abnormal Return (AAR) dan Cummulative Average Abnormal Return(CAAR)

\begin{tabular}{|c|c|c|c|c|}
\hline Hari ke & AAR & Sig. 1-tailed & CAAR & Sig. 1-tailed \\
\hline H-7 & 0.0189 & $0.0010^{*}$ & 0.0189 & $0.0013^{*}$ \\
H-6 & 0.0300 & $0.0000^{*}$ & 0.0489 & $0.0000^{*}$ \\
H-5 & 0.0221 & $0.0000^{*}$ & 0.0709 & $0.0000^{*}$ \\
H-4 & -0.0009 & 0.9300 & 0.0701 & $0.0001^{*}$ \\
H-3 & 0.0111 & 0.1130 & 0.0812 & $0.0000^{*}$ \\
H-2 & 0.0114 & $0.0130^{*}$ & 0.0926 & $0.0000^{*}$ \\
H-1 & 0.0187 & $0.0070^{*}$ & 0.1113 & $0.0000^{*}$ \\
H0 & 0.0184 & $0.0010^{*}$ & 0.1297 & $0.0000^{*}$ \\
H+1 & 0.0392 & $0.0000^{*}$ & 0.1689 & $0.0000^{*}$ \\
H+2 & 0.0297 & $0.0000^{*}$ & 0.1986 & $0.0000^{*}$ \\
H+3 & 0.0255 & $0.0010^{*}$ & 0.2241 & $0.0000^{*}$ \\
H+4 & 0.0114 & $0.0160^{*}$ & 0.2355 & $0.0000^{*}$ \\
H+5 & 0.0190 & $0.0210^{*}$ & 0.2544 & $0.0000^{*}$ \\
H+6 & 0.0107 & $0.0330^{*}$ & 0.2651 & $0.0000^{*}$ \\
H+7 & 0.0005 & 0.9750 & 0.2657 & $0.0000^{*}$ \\
\hline Sumbr & & & & \\
\hline
\end{tabular}

Sumber: Data diolah *) significant ( $\alpha$ ) 5\% 
Berdasarkan Tabel 3. memperlihatkan bahwa reaksi pasar atas pengumuman pembelian kembali saham yang diukur dengan AAR, menunjukkan pasar bereaksi positif signifikan pada 12 hari selama periode event windows dan 3 hari lainnya pasar bereaksi tidak signifikan. Berdasarkan indikator CAAR, pengumuman pembelian kembali direaksi pasar positif signifikan pada semua hari dalam periode event window. Dengan demikian berdasarkan indikator AAR, hasil pengujian hipotesis $\left(\mathrm{H}_{1}\right)$ terbukti pada 12 hari pengujian, dan berdasarkan indikator CAAR terbukti pada 15 hari pengujian, artinya hipotesis $\mathrm{H}_{1}$ diterima pada sebagian besar hari pengujian.

\section{Perbandingan Reaksi Pasar Terhadap Pengumuman Kembali Saham Perusahaan Yang Mengacu Pada Peraturan BAPEPAM-LK No. XI.B.2 dan Peraturan BAPEPAM-LK No. XI.B.3}

Berdasarkan indikator AAR dan CAAR selama event windows, menunjukkan adanya reaksi pasar yang signifikan terhadap pengumuman pembelian kembali saham. Dalam melakukan pembelian kembali saham, ada perusahaan yang melakukannya dengan mengacu pada pada peraturan BAPEPAM-LK No. XI.B.2 sebagai kelompok 1 dan peraturan BAPEPAM-LK No. XI.B.3 sebagai kelompok 2. Untuk mengetahui perbedaan reaksi pasar pada pengumuman pembelian kembali saham berdasarkan kelompok penggunaan peraturan BAPEPAM-LK dapat diuji dengan membandingan AAR dan CAAR pada kedua kelompok perusahaan tersebut dengan menggunakan uji t dua sampel independen dua arah dan $\alpha=5 \%$, yang hasilnya dipaparkan pada Tabel 4.

Pada kelompok 1, average abnormal return (AAR) tertinggi pada $\mathrm{H}+1$ terjadi akibat adanya abnormal return positif yang cukup tinggi pada beberapa perusahaan yang melakukan pengumuman kembali saham pada hari tersebut. AAR terendah pada $\mathrm{H}+7$ terjadi akibat adanya abnormal return negatif yang cukup rendah pada beberapa perusahaan yang melakukan pengumuman kembali saham pada hari tersebut.

Pada kelompok 2, average abnormal return (AAR) tertinggi pada $\mathrm{H}+2$ terjadi akibat adanya abnormal return positif yang cukup tinggi pada beberapa perusahaan yang melakukan pengumuman pembelian kembali saham pada hari tersebut. AAR terendah pada H-4 terjadi akibat adanya abnormal return negatif yang cukup rendah pada beberapa perusahaan yang melakukan pengumuman kembali saham pada hari tersebut.

Berdasarkan Tabel 4. hasil uji t dua dua kelompok sampel memperlihatkan bahwa terdapat perbedaan AAR secara signifikan pada 11 hari periode event windows dan 4 hari lainnya tidak terdapat perbedaan yang signifikan. Hal ini berarti berdasarkan indikator AAR, hipotesis $\mathrm{H}_{2}$ terbukti pada 11 hari pengujian, sedangkan 4 hari pengujian tidak terbukti, dengan kata lain hipotesis $\mathrm{H}_{2}$ diterima pada sebagian besar hari pengujian. 
Tabel 4. Perbandingan Data AAR dan CAAR Hasil Uji Signifikansi Sekitar Tanggal Pengumuman Pembelian Kembali Saham Berdasarkan Kelompok Perusahaan

\begin{tabular}{|c|c|c|c|c|c|c|}
\hline Hari & \multicolumn{3}{|c|}{ AAR } & \multicolumn{3}{c|}{ CAAR } \\
\cline { 2 - 6 } Ke - & $\begin{array}{c}\text { Kelompok } \\
\mathbf{1}\end{array}$ & $\begin{array}{c}\text { Kelompok } \\
\mathbf{2}\end{array}$ & $\begin{array}{c}\text { Sig. 2- } \\
\text { tailed }\end{array}$ & $\begin{array}{c}\text { Kelompok } \\
\mathbf{1}\end{array}$ & $\begin{array}{c}\text { Kelompok } \\
\mathbf{2}\end{array}$ & $\begin{array}{c}\text { Sig. 2- } \\
\text { tailed }\end{array}$ \\
\hline H-7 & 0.0306 & 0.0046 & $0.0196^{*}$ & 0.0306 & 0.0046 & $0.0196^{*}$ \\
H-6 & 0.0456 & 0.0109 & $0.0100^{*}$ & 0.0762 & 0.0155 & $0.0012^{*}$ \\
H-5 & 0.0248 & 0.0187 & 0.5977 & 0.1010 & 0.0342 & $0.0045^{*}$ \\
H-4 & 0.0263 & -0.0341 & $0.0001^{*}$ & 0.1274 & 0.0001 & $0.0000^{*}$ \\
H-3 & 0.0338 & -0.0165 & $0.0002^{*}$ & 0.1611 & -0.0164 & $0.0000^{*}$ \\
H-2 & 0.0207 & 0.0000 & $0.0198^{*}$ & 0.1818 & -0.0164 & $0.0000^{*}$ \\
H-1 & 0.0463 & -0.0152 & $0.0000^{*}$ & 0.2282 & -0.0315 & $0.0000^{*}$ \\
H0 & 0.0373 & -0.0046 & $0.0001^{*}$ & 0.2654 & -0.0361 & $0.0000^{*}$ \\
H+1 & 0.0590 & 0.0150 & $0.0065^{*}$ & 0.3244 & -0.0212 & $0.0000^{*}$ \\
H+2 & 0.0360 & 0.0221 & 0.1451 & 0.3604 & 0.0009 & $0.0000^{*}$ \\
H+3 & 0.0283 & 0.0220 & 0.6718 & 0.3887 & 0.0230 & $0.0000^{*}$ \\
H+4 & 0.0252 & -0.0056 & $0.0005^{*}$ & 0.4139 & 0.0174 & $0.0000^{*}$ \\
H+5 & 0.0371 & -0.0032 & $0.0111^{*}$ & 0.4510 & 0.0142 & $0.0000^{*}$ \\
H+6 & 0.0313 & -0.0144 & $0.0000^{*}$ & 0.4822 & -0.0002 & $0.0000^{*}$ \\
H+7 & 0.0011 & -0.0001 & 0.9714 & 0.4833 & -0.0004 & $0.0000^{*}$ \\
\hline
\end{tabular}

Sumber: Data diolah. *) Significant $(\alpha) 5 \%$

.Berdasarkan indikator CAAR kelompok 1 mengindikasikan pasar bereaksi positif disekitar tanggal pengumuman pembelian kembali saham. Pada kelompok 2, nilai CAAR berfluktuasi sangat tipis dengan perbandingan nilai positif dan negatif yang seimbang. Hasil uji hipotesis menunjukkan bahwa berdasarkan indikator CAAR terdapat perbedaan yang signifikan antara kelompok 1 dan kelompok 2 pada semua hari pengujian. Hal ini berarti hipotesis $\mathrm{H}_{2}$ terbukti pada semua hari pengujian, dengan kata lain hipotesis $\mathrm{H}_{2}$ dapat diterima. 


\section{PEMBAHASAN}

\section{Reaksi Pasar Terhadap Pengumuman Pembelian Kembali Saham}

Berdasarkan hasil analisis Tabel 3 menunjukkan bahwa untuk keseluruhan sampel hasil uji AAR sebagian besar mengindikasikan terjadi reaksi pasar yang positif, kecuali pada $\mathrm{H}-4$ terjadi reaksi pasar negatif. Hasil uji statistik menunjukkan 12 hari selama periode uji terjadi AAR yang signifikan sedangkan 3 hari tidak signifikan. Ditinjau dari indikator CAAR menunjukkan bahwa selama periode uji keseluruhan CAAR mengindikasikan reaksi pasar yang positif signifikan.

Hal ini terjadi karena pengumuman pembelian kembali saham merupakan tindakan korporasi yang akan berdampak pada peningkatan harga saham di pasar modal. Peningkatan harga saham akan berakibat pada peningkatan pendapatan saham (actual return) yang pada akhirnya akan meningkatkan AAR. Hasil penelitian ini konsisten dengan penelitian yang dilakukan oleh Rasbrant (2011), Nittayagasetwat et al (2013) dan Junizar (2013) yang menemukan adanya abnormal return yang positif secara signifikan disekitar tanggal pengumuman pembelian kembali saham.

\section{Perbandingan Reaksi Pasar Terhadap Pengumuman Kembali Saham Perusahaan Yang Mengacu Pada Peraturan BAPEPAM-LK No. XI.B.2 dan Peraturan BAPEPAM-LK No. XI.B.3}

Berdasarkan hasil analisis perbandingan Tabel 4, menunjukkan bahwa pengumuman pembelian kembali saham yang berdasarkan peraturan BAPEPAM-LK No. XI.B.2 (kelompok 1) selalu direaksi pasar secara positif selama periode pengujian baik dilihat dari indikator AAR maupun CAAR, dibandingkan dengan pengumuman pembelian kembali saham yang berdasarkan peraturan BAPEPAM-LK No. XI.B.3 (kelompok 2) yang menunjukkan terdapat reaksi pasar negatif selama periode pengujian.

Hal ini terjadi karena peraturan BAPEPAM-LK No. XI.B.2 dikeluarkan untuk perusahaan yang melakukan pembelian kembali saham pada kondisi normal, sehingga memberikan sinyal yang positif bagi investor. Dalam kondisi normal dengan adanya pengumuman pembelian kembali saham, investor berharap terjadi kenaikan harga saham, karena jumlah saham yang beredar akan berkurang. Apabila permintaan terhadap saham tetap, maka harga saham akan naik sehingga meningkatkan pendapatan saham.

Pengumuman pembelian kembali saham yang berdasarkan peraturan BAPEPAM-LK No. XI.B.3 dikeluarkan sebagai respon atas krisis global tahun 2008 yang berdampak pada turunnya indeks harga saham gabungan (IHSG) di bursa efek Indonesia.

Dengan demikian pengumuman pembelian kembali saham berdasarkan peraturan BAPEPAM-LK No. XI.B.3 tidak semata-mata untuk kepentingan perusahaan secara individu, tetapi juga untuk meningkatkan IHSG yang saat itu sedang turun secara drastis. Oleh karena itu terjadi reaksi pasar berbeda dibandingkan dengan pengumuman pembelian kembali saham pada kondisi pasar yang normal. Pada kondisi krisis, pengumuman pembelian kembali saham tidak bisa meningkatkan harga saham sebagaimana pada kondisi normal, sehingga masih terjadi AAR maupun CAAR yang negatif ketika kondisi krisis.

Bila dilihat dari perusahaan yang tergabung pada kelompok 2, dapat dilihat bahwa perusahaan yang melakukan pengumuman pembelian kembali saham yang dijadikan sampel 
penelitian mayoritas adalah perusahaan yang melakukan pengumuman pembelian kembali saham pada tahun 2008 yaitu 25 perusahaan dan hanya 2 perusahaan saja yang melakukan pengumuman pembelian kembali saham pada tahun 2010. Tahun 2008 adalah tahun dimana Indonesia menghadapi ancaman krisis keuangan akibat krisis keuangan yang terjadi di luar negeri, sehingga lebih berpengaruh daripada sinyal informasi yang dikeluarkan oleh perusahaan dalam bentuk pengumuman pembelian kembali saham.

Dengan demikian perusahaan sebaiknya melakukan pengumuman pembelian kembali saham jika kondisi ekonomi normal. Hal ini karena pada kondisi ekonomi yang normal reaksi pasar terhadap pengumuman pembelian kembali saham adalh positif, sedangkan pada kondisi krisis cendrung direaksi negatif.

\section{SIMPULAN}

Berdasarkan analisis dan pembahasan penelitian yang telah dilakukan, maka dapat diambil beberapa kesimpulan sebagai berikut :

1. Terjadi reaksi pasar positif signifikan di sekitar pengumuman pembelian kembali saham yang ditunjukkan dengan nilai AAR dan CAAR yang siginifikan.

2. Terdapat perbedaan reaksi pasar yang signifikan antara perusahaan yang melakukan pengumuman pembelian kembali saham dengan mengacu pada peraturan BAPEPAMLK No. XI.B.2 tentang pembelian kembali saham emiten pada kondisi normal dengan yang mengacu pada peraturan BAPEPAM-LK No. XI.B.3 tentang pembelian kembali saham emiten pada kondisi pasar berpotensi krisis, ditunjukkan dengan adanya perbedaan AAR dan CAAR yang signifikan antara dua kelompok perusahaan tersebut.

3. Reaksi pasar terhadap perusahaan pada kelompok 1 yaitu perusahaan yang melakukan pengumuman pembelian kembali saham dengan mengacu pada peraturan BAPEPAMLK No. XI.B.2 seluruhanya direaksi positif, sedangkan perusahaan pada kelompok 2 yaitu perusahaan yang mengacu pada peraturan BAPEPAM-LK no. XI.B.3 ada sebagian yang direaksi negatif.

4. Pengumuman pembelian kembali saham sebaiknya dilakukan pada kondisi ekonomi yang normal, karena direaksi positif oleh pasar. 


\section{DAFTAR PUSTAKA}

Amalia, Nur S. 2010. "Reaksi Pasar atas Pengumuman PROPER Terhadap Abnormal Return dan Volume Perdagangan Saham". Skripsi Fakultas Ekonomika dan Bisnis Universitas Diponegoro, Semarang.

Ariyanto, Budi. 2009. "Pengaruh Merger atau Akuisisi Terhadap Volume Perdagangan dan Harga Saham." Skripsi Fakultas Ekonomika dan Bisnis Universitas Diponegoro, Semarang.

Asquith, Paul, and David W. Mullins, Jr. 1986. "Signaling with Dividends, Stock epurchases, and Equity Issues". Financial Management. p. 27-44.

Bahrum, Devina. 2009. "Pengaruh Pengumuman Marger dan Akuisisi Terhadap Reaksi Pasar pada Perusahaan di Bursa Efek Indonesia”. Skripsi Fakultas Ekonomika dan Bisnis Universitas Diponegoro, Semarang.

Elton. E.J dan M. Gruber, 1995, Modern Portfolio Theory and Investment Analysis, Ed.5, John Willy and Sons Inc, Toronto.

Fama F. Eugene, 1991, Efficient Capital Market II, Journal of Finance, Vol.XLVI No. 5, December.

Grullon, Gustavo, and Roni Michaely. 2002. "Dividends, Share Repurchases and the Substitution Hypothesis". Journal of Finance 57, h. 1649-1684.

Muhammad Luky Junizar dan Aditya Septiani,2013, "Pengaruh Pengumuman Pembelian Kembali Saham (Buy Back) Terhadap Respon Pasar: Studi Pada Perusahaan Yang Terdaftar Di Bursa Efek Indonesia", Skripsi Fakultas Ekonomika dan Bisnis Universitas Diponegoro, Semarang.

Jogiyanto Hartono, 2008, Teori Portofolio dan Analisis Investasi, BPFEYogyakarta, Edisi Kelima, Yogyakarta.

Jogiyanto Hartono, 2005, Pasar Efisien secara Keputusan, PT Gramedia Pustaka Utama, Jakarta.

Mackinlay, A. Craig, 1997. Event Studies in Economics and Finance, Journal ofEconomic Literature, Vol.XXXV (March), p.13-39.

Maxwell, William F. And Stephens Clifford P. 2003. "The Wealth Effects of Repurchases on Bondholders." The Journal of Finance, Vol. LVIII, No.2,h. 895-919.

Mulia, Rahma M. 2009. "Pengaruh Stock Repurchase Terhadap Stockholder, Bondholder, dan Value Perusahan di Indonesia Periode 2001-2007”. Skripsi Fakultas Ekonomi Univetsitas Indonesia, Jakarta.

Nishikawa, Takeshi, Prevost, Andrew K., Rao, Ramesh P. 2011. " Bond Market Reaction to Stock Repurchases : is There a Wealth Transfer Effect?" The Journal of Financial Research, Vol. XXXIV, No. 3, p. 503-522.

Peterson, Pamela. P. 1998. Event Studies: A Review of Issues and Methodology, Quarterly, Journal of Business and Economics, Vol.28, No.3, Summer. 
Rasbrant, Jonas. 2011. "The Price Impact of Open Market Share Repurchases", Department of Industrial Economics and Management, KTH Royal Institute of Technology, Sweden.

Rinaningtias, Resti D. 2009. "Reaksi Pasar Modal Terhadap Peristiwa Bom J.W. Marriott dan Ritz Carlton 17 Juli 2009". Skripsi Fakultas Ekonomika dan Bisnis Universitas Diponegoro. Semarang.

Rudi Hermawan. 2004. "Reaksi Pasar terhadap Pergantian Presiden", Tesis (tidak dipublikasikan), Magister Manajemen Universitas Airlangga, Semarang

Samsul, Mohammad. 2006. "Pasar Modal dan Manajemen Portofolio". Erlangga, Surabaya.

Saud Husnan. 2005. "Dasar-dasar Teori Portofolio dan Analisis Sekuritas". Edisi Kelima, BPFE, Yogyakarta.

Sant, Rajiv dan Ferris, Stephen, 1994, Seasoned Equity Offering: The Cases of All Equity Firm, Journal of Business Finance and Accounting (JBFA), 21 (3),April, p.429-444

Sudana, I Made. 2011. "Manajemen Keuangan Perusahaan, Teori dan Praktek". Erlangga, Jakarta.

Tandelilin, Eduardus. 2001. "Analisis Investasi dan Manajemen Portofolio". BPFE UGM: Yogyakarta.

Treisye Arience Lamasigi. 2002. "Reaksi Pasar Modal Terhadap PeristiwaPergantian Presiden Republik Indonesia 23 Juli 2001: Kajian TerhadapReturn Saham LQ-45 di PT. Bursa efek Jakarta”, Simposium NasionalAkuntansi IV, 5-6 September, Semarang.

Vermaelen, T. (1981). Common stock repurchases and market signaling. Journal of Financial Economics, 9(2), 139-183.

Wansley, James W., William R. Lane, and Salil Sarkar. (1989). Management's View on Share Repurchase and Tender Offer Premiums. Financial Management. 91-110.

WiyadaNittayagasetwat and Aekkachai Nittayagasetwat, 2013,Common Stock Repurchases: Case of Stock Exchange of Thailand, International Journal of Business and Social Science, Vol. 4 No. 2 (February) 